\title{
Effects of soil properties and fertilization on quality and biological activity of Swiss chard
}

\author{
A. Topalović ${ }^{1}$, M. Knežević ${ }^{1}$, S. Trifunović ${ }^{2}$, M. Novaković 3 , M. Pešić ${ }^{4}$ and D. Đurović ${ }^{5}$ \\ ${ }^{1}$ University of Montenegro, Biotechnical Faculty, Center for Soil Research and Melioration, Podgorica, Montenegro \\ ${ }^{2}$ University of Belgrade, Faculty of Chemistry, Belgrade, Serbia \\ ${ }^{3}$ University of Belgrade, Institute of Chemistry, Technology and Metallurgy, National Institute, Belgrade, Serbia \\ ${ }^{4}$ University of Belgrade, Institute for Biological Research, Belgrade, Serbia \\ ${ }^{5}$ Institute for Public Health, Podgorica, Montenegro
}

\section{Summary}

Swiss chard (Beta vulgaris L. var. cicla) is a leafy vegetable highly consumed in many parts of the world as a very popular ingredient of different diets. The purpose of this study was to evaluate effects of soil properties and fertilization on yield, mineral composition, total phenolics, antioxidant and biological activity of Swiss chard. The mineral composition of Swiss chard was generally affected by soil properties. The fertilization at $50 \%$ of recommended level (110 $\mathrm{kg} \mathrm{ha}^{-1} \mathrm{~N}, 90 \mathrm{~kg} \mathrm{ha}^{-1} \mathrm{P}_{2} \mathrm{O}_{5}$ and $100 \mathrm{~kg} \mathrm{ha}^{-1} \mathrm{~K}_{2} \mathrm{O}$ per season) affected negatively yield and on the other hand affected positively antioxidant activity, while fertilization at $150 \%$ of recommended level had a contrary effect. The available $K$ in soil affected the yield positively. Total phenolics were in negative correlation with the yield. The positive relationship of total phenolics and content of $\mathrm{Mn}$ in chard was noticed. The greatest efficacy in human colorectal carcinoma cell lines was obtained by Swiss chard extract from plants fertilized at $150 \%$ of recommended level.

\section{Keywords}

antioxidant activity, cell growth inhibition, colorectal carcinoma, crude extract, mineral content, total phenolics, yield

\section{Introduction}

Numerous epidemiological studies have shown that fruits and vegetables have a protective effect against several chronic diseases associated with aging such as cancer, cardiovascular disease, cataracts, brain and immune dysfunction. Protective activity has been attributed to various components, mainly antioxidants, such as carotenoids, vitamins $\mathrm{C}$ and $\mathrm{E}$, and phenolic compounds, mainly flavonoids (Pyo et al., 2004; Schirrmacher et al., 2010; Ninfali and Angelino, 2013). These natural antioxidant compounds are known to minimise the adverse effects of reactive species generated by various metabolic processes and environmental stresses in living systems. (Mishra et al., 2010). The role of free radicals and other 'reactive oxygen/nitrogen/chlorine species' is widely recognized in the development of the diseases mentioned above (Topalović et al., 2013; Trifunović et al., 2015). Many studies have focused on the biological activities of phenolics, which are potent antioxidants and free-radical scavengers. The antioxidant activity of phenolics is attributed mainly to their redox properties, which enable them to

\section{Significance of this study}

What is already known on this subject?

- Swiss chard possesses high nutritional value and anti-diabetic, anti-inflammatory, antioxidant and anticancer activities of chard extracts that are linked to bioactive molecules such as phenolic compounds. Increase in level of nitrogen fertilization over $100 \mathrm{~kg}$ $\mathrm{N}^{-1}{ }^{-1}$ produces taller and leafier plants with higher fresh weight but reduced dry matter content. The content of ascorbic acid as antioxidant rises with increase of nitrogen supply.

What are the new findings?

- The NPK fertilization at $50 \%$ of recommended level reduces the yield and has a positive effect on antioxidant activity, while fertilization at $150 \%$ of recommended level has a contrary effect. The fertilization strategies with $50 \%$ and $100 \%$ of nutrient doses are more efficient in research of biological activity of Swiss chard extracts on multidrug resistant colorectal cancer cells (DLD1-TxR) comparing to their sensitive counterparts (DLD1), while 150\% fertilization shows the same efficacy in both cell lines.

What is the expected impact on horticulture?

- The impact of fertilizer doses on yield and quality of Swiss chard, especially on its antioxidant and biological activity.

act as reducing agents, hydrogen donors and singlet oxygen quenchers (Pyo et al., 2004; Topalović et al., 2013). Moreover, they have a metal chelation potential (Kuo et al, 1998; Yoshino and Murakami, 1998). The researches of such antioxidative phenolic compounds in edible plants are conducted to improve the understanding of their dietary value and potential health benefits.

Swiss chard (Beta vulgaris L. var. cicla) is a leafy vegetable highly consumed in many parts of the world. Producers prefer Swiss chard over spinach and celery because it is more robust and easier to grow (Maynard and Hochmuth, 1997). The leaves and the stalks of chard have a high nutritional value with a high concentration of vitamins ( $\mathrm{A}, \mathrm{K}$ and $\mathrm{C}$ ), minerals (potassium, calcium, magnesium, iron and phosphorus), dietary fiber and proteins (Daiss et al., 2008a, b; Pokluda and Kuben, 2002; Bozokalfa et al., 2011). According to USDA National Nutrient Database (2014), in comparison to green 
lettuce, Swiss chard has a considerably higher value for most of minerals, except for $\mathrm{Ca}, \mathrm{K}, \mathrm{Fe}, \mathrm{Mn}, \mathrm{Zn}$ and proteins than spinach. The main identified secondary metabolites are flavonoids, flavonoid glycosides and saponins (Trifunović et al., 2015). Modern pharmacologists address the importance of bioactive molecules from the chard extracts and demonstrate their anti-diabetic, anti-inflammatory, antioxidant and anticancer activities (Ninfali and Angelino, 2013).

In general, a small number of researches are undertaken considering the effects of soil properties and fertilization on quality parameters of Swiss chard. Additionally, there is no literature data reporting the effects of fertilization on phenolic composition and biological activity of Swiss chard. The agrochemical conditions of growing the chard on calcareous soil were already characterised (Knežević et al., 2014). The purpose of this study was to: (i) evaluate yield, mineral composition, total phenolics and potential for antioxidant activity of Swiss chard that were grown under different fertilizer treatments; (ii) determine relationships between chard and soil parameters; and (iii) estimate anti-colorectal carcinoma activity of crude extracts of Swiss chard.

\section{Materials and methods}

\section{Trial setup}

The experimental field is located on $42.553191^{\circ} \mathrm{N}$ latitude and $19.149113^{\circ} \mathrm{E}$ longitude, in the municipality of Danilovgrad (Montenegro), in a location called Sige. The soil type is rendzina (rendzic leptosol). According to the ex-Yugoslav soil classification system, rendzina soil type belongs to the order of automorphic soils, class of humus-accumulative soils.

The experiment with Swiss chard (Beta vulgaris L. var. cicla), Verca $\mathrm{F}_{1}$ hybrid (Clause, France) was conducted in March-July, 2014. Soil was prepared for cultivation on March 22. On March 25, seedlings (grown in a greenhouse) with four to five true leaves were transplanted to the field. Planting density was $25 \times 30 \mathrm{~cm}$. Fertilizers were firstly applied on March 22. Fertilization doses corresponded to 50\%, 100\%, and $150 \%$ (F50, F100, F150) of commercial recommendations for Swiss chard, which were $110 \mathrm{~kg} \mathrm{ha}^{-1} \mathrm{~N}, 90 \mathrm{~kg} \mathrm{ha}^{-1}$ $\mathrm{P}_{2} \mathrm{O}_{5}$ and $100 \mathrm{~kg} \mathrm{ha}^{-1} \mathrm{~K}_{2} \mathrm{O}$ per season including 6 harvesting cycles. Fertilization amounts of NPK fertilizer (11:11:21) were $200 \mathrm{~kg} \mathrm{ha}^{-1}, 400 \mathrm{~kg} \mathrm{ha}^{-1}$ and $600 \mathrm{~kg} \mathrm{ha}^{-1}$. Additional nutrient fertilization was applied by watering with the same volume of appropriate solution twice during vegetation, on May 7 and May 27. Both applications consisted of a mixture containing 2/3 of NPK 24:8:16 and 1/3 of NPK 15:30:15. It amounted to $50 \mathrm{~kg} \mathrm{ha}^{-1}, 100 \mathrm{~kg} \mathrm{ha}^{-1}$, and $150 \mathrm{~kg} \mathrm{ha}^{-1}$ for the various treatments. Irrigation amount of $60 \mathrm{~mm}$ of water was applied uniformly to all plots during the season.

Harvesting was conducted four times by cutting (removing) mature leaves with stalks (as for market) manually on May 12, May 23, June 2 and June 12, in the morning. The first yield was mass of chard harvested on May 12. Total yield was the sum of yields for four harvests. Total biomass was the total mass of chard (grown from fourth harvest on June 12), harvested by removal of all plants on June 22, after the hail happened on June 14 .

\section{Soil analysis}

The effect of various rates of fertilizer on the growth of Swiss chard was researched on the same soil type. The experiment had a completely randomized design with nine replicates per treatment. Plot size was $10.5 \mathrm{~m}^{2}$.
Soil samples (totally 27) were collected from a depth of 0-30 cm before fertilization and Swiss chard transplanting. Soil physical and chemical properties were determined by methods described in the handbook of Džamić et al. (1996). Soil reaction in water and $\mathrm{KCl}$ were determined with a combined glass-electrode in soil:deionized water and soil/1M $\mathrm{KCl}$ suspensions 1:2.5 (w/v). Total calcium carbonate was determined by volumetric method. Humus was determined by wet oxidation with $0.02 \mathrm{M} \mathrm{KMnO}_{4}$. Electric conductivity was determined in 1:5 water suspensions. The available phosphorus and potassium (extraction with ammonium-acetatelactate solution (AL) at $\mathrm{pH}$ 3.7) were determined according to Egner-Riehm-Domingo method by the spectrophotometry and flame photometry, respectively. Total nitrogen was determined by Kjeldahl method. The available Fe, Mn, Zn and $\mathrm{Cu}$ (extraction with $0.005 \mathrm{M}$ DTPA) as well as exchangeable $\mathrm{Ca}$ and $\mathrm{Mg}$ (extraction with $1 \mathrm{M} \mathrm{CH}_{3} \mathrm{COONH}_{4}$ ) were determined by flame atomic absorption spectrometry (AA-6800, Shimadzu). The values of mentioned soil parameters are expressed on air-dried basis. Particle size distribution was analyzed by the sieve and the pipette method.

\section{Plant analysis}

1. Chlorophyll content index (CCI). CCI in leaves of Swiss chard was measured in situ before harvest by CCM-200 plus. 2. Nutrients. The content of nutrients was measured after the first harvesting cycle. After microwave digestion (Ethos 1, Milestone) of the chard (edible portion) with $\mathrm{HNO}_{3}$ and $\mathrm{H}_{2} \mathrm{O}_{2}(5: 2)$, the total elemental concentrations (excluding $\mathrm{N}$ ) were determined by ICP-OES (Spectro Arcos). Total nitrogen was determined by Kjeldahl method. The concentrations are expressed on dry matter basis (dried at $105^{\circ} \mathrm{C}$ ). Harvesting cycles included fresh yield measurements after each harvest directly on the field.

3. Extraction for determination of total phenolics and DPPH assay. Frozen sample of Swiss chard was blended and $0.5 \mathrm{~g}$ extracted with $80 \%$ methanol (in water) for $3 \mathrm{~h}$ using an ultrasound bath (adding ice during extraction). The extract was filtered through a $0.45 \mu \mathrm{m}$ polyamide filter (Macherey Nagel, Düren, Germany), transferred to vials and stored at $-20^{\circ} \mathrm{C}$ until analyzed for total phenolics and DPPH assay.

4. Total phenolics. Total phenolic content of Swiss chard extracts (appropriate concentration determined experimentally) was determined by Folin-Ciocalteu (FC) method. A volume of $200 \mu \mathrm{L}$ of extract was mixed with $1000 \mu \mathrm{L}$ of FC reagent diluted with distilled water in proportion 1:10. After 6 min standing in the dark, $800 \mu \mathrm{L}$ of sodium carbonate solution $(7.5 \%)$ was added. After shaking and standing in the dark for additional $2 \mathrm{~h}$, absorbance at $740 \mathrm{~nm}$ was measured. Distilled water was used as blank. All samples were measured in triplicate. The same procedure was applied for four concentrations of gallic acid standards $(10,25,50$ and 100 $\mu \mathrm{g} \mathrm{mL} \mathrm{m}^{-1}$ ) and a calibration curve was calculated. The total phenolic content is expressed in gallic acid equivalents (GAE) - concentration of gallic acid in $\mu \mathrm{g} \mathrm{mL}^{-1}$ that corresponds to the extract with the same value of absorbance at $740 \mathrm{~nm}$.

5. DPPH assay. The potential for free radical scavenging activity of Swiss chard extracts was analyzed by DPPH assay, based on measurement of the loss of 1,1-diphenyl-2-picrylhydrazyl free radical violet colour in reaction with potential antioxidants, monitored by absorbance decrease at $517 \mathrm{~nm}$. A volume of $200 \mu \mathrm{L}$ of Swiss chard extract (appropriate concentration determined experimentally) was mixed with $1800 \mu \mathrm{L}$ of methanolic solution of DPPH $(0.1 \mathrm{mM})$. After shaking and standing for $30 \mathrm{~min}$ in the dark, absorbance at 
$517 \mathrm{~nm}$ was measured. All samples were prepared in triplicate. Potential antioxidant activity was expressed as percentage of inhibition of DPPH radical (I\%) of each extract and was calculated according to equation 1 :

$$
\mathrm{I}(\%)=\left[\left(\mathrm{A}_{\text {blank }}-\mathrm{A}_{\text {sample }}\right) / \mathrm{A}_{\text {blank }}\right] \times 100
$$

where $\mathrm{A}_{\text {blank }}$ is the absorbance of DPPH with $80 \%$ methanol instead of the sample and $\mathrm{A}_{\text {sample }}$ is the absorbance of DPPH after reaction with an extract. Higher value of $\mathrm{I} \%$ means higher potential for antioxidant activity.

6. Colorectal carcinoma cell growth inhibition. DLD1 cell line was purchased from American Type Culture Collection (Rockville, MD, USA). DLD1-TxR cells are a multidrug resistant variant selected from DLD1 cells after continuous exposure to stepwise increasing concentrations of PTX (60$600 \mathrm{nM}$ ) within the period of 10 months (Podolski-Renić et al., 2011). DLD1 and DLD1-TxR cells were maintained in RPMI 1640 containing 10\% FBS, 2 mM L-glutamine and 10,000 $\mathrm{U} \mathrm{mL}^{-1}$ penicillin, $10 \mathrm{mg} \mathrm{mL}^{-1}$ streptomycin, $25 \mathrm{~g} \mathrm{~mL}^{-1}$ amphotericin B solution. The cells were kept at $37^{\circ} \mathrm{C}$ in humidified $5 \% \mathrm{CO}_{2}$ atmosphere and subcultured at $72 \mathrm{~h}$ intervals using $0.25 \%$ trypsin/EDTA.

The effects of whole Swiss chard extracts of control (non-fertilized) and fertilized (at mentioned levels of 50\%, $100 \%$ and $150 \%$ ) samples were assessed by sulforhodamine $\mathrm{B}$ (SRB) assay. Cells grown in $25 \mathrm{~cm}^{2}$ tissue flasks were trypsinized, seeded into flat-bottomed 96-well tissue culture plates (1000 cell well $\left.{ }^{-1}\right)$ and incubated for an overnight. Later the cells were treated for $72 \mathrm{~h}$ with various concentrations of extracts $\left(5,10,25,50\right.$ and $\left.100 \mu \mathrm{g} \mathrm{mL}^{-1}\right)$ initially resolved in ethanol to obtain a stock concentration of $10 \mathrm{mg} \mathrm{mL}^{-1}$. Sulforhodamine $\mathrm{B}$ binds to the cell proteins enabling the detection of differences in cell viability between untreated and treat- ed cells. To be brief, the cells in 96-well plates were fixed in $50 \%$ trichloracetic acid $\left(50 \mu \mathrm{L}\right.$ well- $\left.{ }^{-1}\right)$ for $1 \mathrm{~h}$ at $4^{\circ} \mathrm{C}$, rinsed in tap water and stained with $0.4 \%(\mathrm{w} / \mathrm{v})$ SRB in $1 \%$ acetic acid (50 $\mu \mathrm{L}$ well $\left.^{-1}\right)$ for $30 \mathrm{~min}$ at room temperature. The cells were then rinsed three times in $1 \%$ acetic acid to remove the unbound stain. The protein bound stain was extracted with $200 \mu \mathrm{L} 10 \mathrm{mM}$ Trisbase (pH 10.5) per well. The optical density was read at $540 \mathrm{~nm}$ with correction at $670 \mathrm{~nm}$ in a Micro plate reader (LKB 5060-006, Vienna, Austria).

\section{Statistical analysis}

The statistical analysis of the data was performed by IBM SPSS, version 23, and GrafPad Prism 6.01 for Windows. The significant differences between the means were determined with the one-way ANOVA and Duncan's test at $\mathrm{p}<0.05$. Principal component analysis (PCA) with Varimax rotation was used to examine the intrinsic variation in the data set.

Two-way ANOVA and Sidak's multiple comparisons test at $\mathrm{p}<0.05$ were applied in order to assess significant differences in sensitivity of DLD1 and DLD1-TxR cells to Swiss chard extracts. IC50 values (the concentration of the drug that inhibited cell growth by $50 \%$ ) were calculated by non-linear regression analysis using GraphPad Prism 6.01.

\section{Results and discussion}

The descriptive statistics (minimal, maximal and mean values with standard deviation) of investigated soil and chard parameters are given in Tables 1 and 2. The content of dry matter in chard was $7.97 \%$.

Analysis of soil samples taken before fertilization and Swiss chard transplanting showed adequate conditions for plant growth. Neutral and alkaline soils, with low to very high content of total carbonates, rich and very rich in organic matter (humus), had medium to high level of almost all nutrients

TABLE 1. Descriptive statistics for soil parameters - $\left(\mathrm{pH}\left(\mathrm{H}_{2} \mathrm{O}\right)\right.$ : active acidity, $\mathrm{pH}(\mathrm{KCl})$ : potential acidity, EC: electrical conductivity, concentrations - Soil TN: total nitrogen, $\mathrm{CaCO}_{3}$ : total carbonates, $\mathrm{P}_{2} \mathrm{O}_{5}$ : available phosphorus; $\mathrm{K}_{2} \mathrm{O}$ : available potassium, Soil Ca: exchangeable calcium, Soil Mg: exchangeable magnesium, Soil Fe: available iron, Soil Mn: available manganese, Soil $\mathrm{Cu}$ : available copper, Soil $\mathrm{Zn}$ : available zinc).

\begin{tabular}{|c|c|c|c|c|}
\hline Soil layer $(0-30 \mathrm{~cm})$ & Minimum & Maximum & Mean & SD \\
\hline Soil TN, \% & 0.22 & 0.28 & 0.25 & 0.02 \\
\hline $\mathrm{pH}\left(\mathrm{H}_{2} \mathrm{O}\right)$ & 7.55 & 7.94 & 7.81 & 0.12 \\
\hline $\mathrm{pH}(\mathrm{KCl})$ & 7.02 & 7.41 & 7.27 & 0.11 \\
\hline $\mathrm{CaCO}_{3}, \%$ & 2.30 & 39.00 & 19.61 & 13.59 \\
\hline Humus, $\%$ & 3.50 & 6.25 & 5.42 & 0.82 \\
\hline $\mathrm{P}_{2} \mathrm{O}_{5}, \mathrm{mg} 100 \mathrm{~g}^{-1}$ & 4.20 & 21.60 & 9.02 & 4.97 \\
\hline $\mathrm{K}_{2} \mathrm{O}, \mathrm{mg} 100 \mathrm{~g}^{-1}$ & 16.20 & 32.70 & 21.85 & 5.09 \\
\hline $\mathrm{EC}, \mu \mathrm{S} \mathrm{cm}-1$ & 145.40 & 163.30 & 153.66 & 5.38 \\
\hline Soil Ca, mg $100 \mathrm{~g}^{-1}$ & 698.00 & 2266.00 & 1704.92 & 656.44 \\
\hline Soil Mg, mg $100 \mathrm{~g}^{-1}$ & 18.60 & 25.10 & 22.19 & 2.24 \\
\hline Soil Fe, mg kg-1 & 12.60 & 20.60 & 14.81 & 2.45 \\
\hline Soil Mn, mg kg-1 & 7.00 & 11.90 & 9.04 & 1.43 \\
\hline Soil $\mathrm{Cu}, \mathrm{mg} \mathrm{kg}^{-1}$ & 1.55 & 2.25 & 1.85 & 0.25 \\
\hline Soil Zn, mg kg-1 & 1.23 & 3.04 & 1.95 & 0.57 \\
\hline Coarse sand, \% & 3.18 & 9.52 & 5.76 & 2.12 \\
\hline Fine sand, $\%$ & 33.05 & 51.44 & 44.20 & 6.24 \\
\hline Silt, \% & 8.35 & 38.62 & 22.39 & 9.00 \\
\hline Clay, \% & 12.92 & 41.02 & 27.65 & 10.22 \\
\hline
\end{tabular}


(Table 1). The soil texture includes size classes - coarse and fine sand, silt and clay. Based on International Soil Science Society (ISSS) classification (Baize, 1993), there were four textural classes: sandy clay, loam, light clay and clay loam.

The results of chemical analysis of the chard on nutrients (Table 2) were compared with the literature data. The concentrations in USDA National Nutrient Database (2014) originally given in fresh mass of raw chard, but recalculated on dry mass basis of chard were: proteins: $245.23 \mathrm{~g} \mathrm{~kg}^{-1}, \mathrm{P}$ : $6.27 \mathrm{~g} \mathrm{~kg}^{-1}, \mathrm{~K}: 51.63 \mathrm{~g} \mathrm{~kg}^{-1}$, Ca: $6.95 \mathrm{~g} \mathrm{~kg}^{-1}, \mathrm{Mg}: 11.04 \mathrm{~g} \mathrm{~kg}^{-1}$, Na: $29.02 \mathrm{~g} \mathrm{~kg}^{-1}$, Fe: $245.23 \mathrm{mg} \mathrm{kg}^{-1}$, Mn: $49.86 \mathrm{mg} \mathrm{kg}^{-1}$, Zn: 49.05 $\mathrm{mg} \mathrm{kg}^{-1}, \mathrm{Cu}: 24.39 \mathrm{mg} \mathrm{kg}^{-1}$. Therefore, the concentrations of phosphorus, potassium, sodium, magnesium, iron, zinc and copper in the chard from our trial was lower, but of calcium, manganese and protein (calculated from $\mathrm{N}$ content) higher in comparison to these concentrations. On the other hand, the mineral composition of chard from our trial was in compliance with the results of Bozokalfa et al. (2011), who studied 54 genetically diverse Swiss chard accessions, except for the content of $\mathrm{Ca}, \mathrm{Mn}$, and $\mathrm{Na}$, which were also higher in our case. In relation to $\mathrm{Ca}$, the higher concentration was expected due to chard growing on calcareous soils, with average content of total carbonates $19.61 \% \mathrm{CaCO}_{3}$ (Table 1). The high concentration of $\mathrm{Mn}$ in Swiss chard could be explained by the ability of Swiss chard to accumulate excessive amounts of Mn (Gebrekidan et al., 2013). The $\mathrm{N}$ fertilization affects the protein content in the chard, but in the study there was no significant difference in the content of $\mathrm{N}$ in chard per treatments. Although the amount of applied $\mathrm{N}$ in the study was notably lower than 100-150 $\mathrm{kg} \mathrm{N}^{-1}$ (optimal and environmentally friendly level), e.g., in treatment F50, no effects on the content of $\mathrm{N}$ (i.e., proteins) was found. Moreover, it was higher in comparison to USDA value. Given the trial was setup on agricultural soil rich in total $\mathrm{N}$ (Table 1), the chard was supplied with sufficient $\mathrm{N}$. Therefore, the conditions of cultivation of Swiss chard led to no significant loss in yield and quality for Swiss chard which is in line to Miceli and Miceli (2014). The yield achieved with four harvests was approximately $32 \mathrm{t} \mathrm{ha}^{-1}$.

The total concentration of phenolics in chard cultivated under reduced fertilization was similar to one found in a study of Pyo et al. (2004). The highest value for DPPH was found in crude extract of Swiss chard (50 mg mL $\mathrm{m}^{-1}$ ) from mentioned treatment (Table 2).

The results of one-way ANOVA with Duncan test for all chard parameters showed significant difference related to the amount of first harvest $(\mathrm{F}=7.249 ; \mathrm{p}=0.025)$ and antioxidant activity $(\mathrm{F}=10.815 ; \mathrm{p}=0.010)$ between treatments with $50 \%$ and $150 \%$ fertilizer doses. Namely, the means for mentioned parameters and treatments were $4.22 \mathrm{~kg} \mathrm{parcel}^{-1}$ and $8.52 \mathrm{~kg} \mathrm{parcel}^{-1}$, and $41.69 \%$ and $30.03 \%$ DPPH, respectively (Table 2). In addition, the significance values for total phenolics, total yield, and nitrogen in chard were relatively close to level 0.050. Having in mind correlations between these parameters, the results indicated that fertilization at $50 \%$ of recommended level had a negative effect on yield and positive on antioxidant activity, while fertilization at $150 \%$ of recommended level had a contrary effect.

In order to investigate and avoid possible shortcomings in interpretation of relationships between soil properties and yield and quality of Swiss chard, PCA and Pearson bivariate correlations (not shown) were used. The original set of totally 34 correlated soil and chard parameters, were transformed into four mutually uncorrelated factors (Table 3) according to Topalović et al. (2006). They accounted for about $78 \%$ of total variance. The communalities of soil parameters, considering four factors, varied from about 58\% for fine sand to $94 \%$ for available zinc, and of chard parameters from about $27 \%$ for copper to $95 \%$ for total biomass.

Factor 1 was composed of two complementary groups of parameters - first: active and potential acidity, exchangeable $\mathrm{Ca}$, coarse sand, exchangeable $\mathrm{Mg}$, total carbonates in soil, as well as $\mathrm{Mg}, \mathrm{Zn}, \mathrm{Ca}$ and $\mathrm{N}$ in chard; second: available $\mathrm{Mn}, \mathrm{Cu}$ and $\mathrm{Fe}$, total $\mathrm{N}$ and available $\mathrm{K}$ in soil.

Factor 2 consisted of soil parameters - coarse sand, exchangeable $\mathrm{Mg}$, total carbonates, available $\mathrm{Zn}$ and $\mathrm{P}$ and chard parameters - P and B which had positive loadings; and of humus, EC and available $\mathrm{K}$ in soil and chard $\mathrm{Na}$ and $\mathrm{Cu}$ with negative loadings.

TABLE 2. Parameters of Swiss chard (mean \pm st.dev) sampled on $12^{\text {th }}$ May (mass of yield, concentration of elements in leaves of chard)*.

\begin{tabular}{|c|c|c|c|}
\hline Treatment & F50 & F100 & F150 \\
\hline First yield, $\mathrm{kg} \mathrm{parcel}^{-1}$ & $4.22 \pm 0.90 a$ & $6.42 \pm 0.55 \mathrm{ab}$ & $8.52 \pm 2.15 b$ \\
\hline Total yield, $\mathrm{kg}_{\text {parcel-1 }}$ & $27.37 \pm 3.86$ & $31.60 \pm 6.30$ & $41.77 \pm 8.29$ \\
\hline Total biomass, kg parcel-1 & $40.33 \pm 5.02$ & $44.17 \pm 6.90$ & $56.03 \pm 10.43$ \\
\hline Total phenolics, mg GAE $100 \mathrm{~g}^{-1}$ & $153.13 \pm 7.91$ & $134.80 \pm 5.96$ & $124.87 \pm 17.85$ \\
\hline DPPH, \% & $41.69 \pm 3.01 \mathrm{~b}$ & $35.38 \pm 0.29 a$ & $30.03 \pm 4.38 a$ \\
\hline Chard $\mathrm{N}, \mathrm{g} \mathrm{kg}^{-1}$ & $44.90 \pm 1.95$ & $47.60 \pm 2.42$ & $49.40 \pm 1.04$ \\
\hline Chard P, $\mathrm{g} \mathrm{kg}^{-1}$ & $4.77 \pm 1.61$ & $4.63 \pm 0.91$ & $4.97 \pm 1.32$ \\
\hline Chard Ca, $\mathrm{g} \mathrm{kg}^{-1}$ & $24.96 \pm 2.99$ & $25.99 \pm 4.54$ & $28.59 \pm 2.63$ \\
\hline Chard $\mathrm{K}, \mathrm{g} \mathrm{kg}^{-1}$ & $46.52 \pm 4.52$ & $44.74 \pm 5.11$ & $46.76 \pm 2.43$ \\
\hline Chard Mg, $\mathrm{g} \mathrm{kg}^{-1}$ & $7.32 \pm 0.74$ & $8.17 \pm 1.41$ & $7.40 \pm 0.57$ \\
\hline Chard $\mathrm{Na}, \mathrm{g} \mathrm{kg}^{-1}$ & $23.91 \pm 8.23$ & $23.80 \pm 5.49$ & $18.58 \pm 3.71$ \\
\hline Chard B, mg kg-1 & $16.47 \pm 2.90$ & $15.66 \pm 1.45$ & $16.12 \pm 3.39$ \\
\hline Chard $\mathrm{Cu}, \mathrm{mg} \mathrm{kg}^{-1}$ & $12.67 \pm 0.29$ & $14.29 \pm 1.95$ & $13.08 \pm 0.70$ \\
\hline Chard Fe, $\mathrm{mg} \mathrm{kg}^{-1}$ & $113.21 \pm 21.20$ & $103.78 \pm 11.43$ & $129.82 \pm 30.10$ \\
\hline Chard $\mathrm{Mn}, \mathrm{mg} \mathrm{kg}^{-1}$ & $190.32 \pm 38.80$ & $177.75 \pm 17.30$ & $141.15 \pm 23.61$ \\
\hline Chard Zn, mg kg-1 & $30.83 \pm 3.21$ & $34.00 \pm 2.37$ & $33.60 \pm 3.54$ \\
\hline
\end{tabular}

* Different letters in row indicate significantly different values at $p<0.05$. 
Factor 3 had positive loadings for soil parameters - N, silt and available $\mathrm{K}$ and for chard parameters - all harvests (total yield, biomass and first harvest) and $\mathrm{N}$, but negative loadings for chard total phenolics, antioxidant activity and Mn.

Factor 4 was defined by silt, fine sand, $\mathrm{K}$ and $\mathrm{Fe}$ in chard, which was in negative correlation with clay and available soil $P$.

Regarding the aspect of soil fertility there was a clear grouping of parameters in carbonate component on one side, and organic matter together with electrical conductivity on the other.

The contents of $\mathrm{Ca}, \mathrm{Mg}$, and $\mathrm{P}$ in chard were in positive relationship with its exchangeable/available concentration in soil. Positive relationship between zinc in chard and soil carbonate component indicated that $\mathrm{Zn}$ bound to carbonates could be suitable for uptake by chard. Other positive relationships were found between phosphorus and boron in chard and total carbonates in soil. It is widely known that calcium carbonate acts as an important sink for P (Topalović et al., 2006) and B (Goldberg, 1997) adsorption in calcareous soils. Low molecular organic acids in root exudates may greatly affect plant availability of nutrients in the rhizosphere, and increase their uptake rates and contents in the plants (Ström, 1997; Wu and Zhao, 2013). Increased availability of these nutrients may be related to exuded organic acids stems either the lower $\mathrm{pH}$ of the rhizosphere, or the chelation of microelements (such as $\mathrm{Zn}$ ), and lowering the $\mathrm{Ca}^{2+}$ concentration by chelation and formation of sparingly soluble salts (Marschner, 1995). In addition, through the effect of $\mathrm{pH}$ on surface charge of oxyhydroxides, the nutrient availability for plant-uptake may be increased (Stumm, 1992; Topalović et al., 2006).

EC and total carbonates had an important role in controlling the uptake of $\mathrm{Cu}$ by chard. Namely, the content of $\mathrm{Cu}$ in chard was in positive relationship with EC and negative with

TABLE 3. Factor analysis for Swiss chard and soil: Eigenvalues, cumulative of the total variance, factor loading of the 4 factors, and communality estimates of the 34 parameters.

\begin{tabular}{|c|c|c|c|c|c|}
\hline & Factor 1 & Factor 2 & Factor 3 & Factor 4 & Commun. \\
\hline Eigenvalue & 8.188 & 7.421 & 7.139 & 3.682 & \\
\hline Cumulative, \% & 24.08 & 45.91 & 66.91 & 77.74 & \\
\hline $\mathrm{pH}(\mathrm{KCl})$ & 0.903 & & & & 0.860 \\
\hline $\mathrm{pH}\left(\mathrm{H}_{2} \mathrm{O}\right)$ & 0.878 & & & & 0.866 \\
\hline Soil Ca & 0.842 & & & & 0.931 \\
\hline Soil Mn & -0.798 & & & & 0.906 \\
\hline Soil $\mathrm{Cu}$ & -0.739 & & & & 0.808 \\
\hline Coarse sand & 0.737 & 0.522 & & & 0.912 \\
\hline Soil Fe & -0.727 & & & & 0.729 \\
\hline Chard Mg & 0.722 & & & & 0.641 \\
\hline Soil Mg & 0.683 & 0.507 & & & 0.831 \\
\hline Soil N & -0.662 & & 0.514 & & 0.903 \\
\hline $\mathrm{CaCO}_{3}$ & 0.614 & 0.611 & & & 0.888 \\
\hline Chard Zn & 0.552 & & & & 0.447 \\
\hline Chard Ca & 0.489 & & & & 0.315 \\
\hline Chard P & & 0.946 & & & 0.920 \\
\hline Soil Zn & & 0.936 & & & 0.942 \\
\hline Chard B & & 0.905 & & & 0.901 \\
\hline Humus & & -0.797 & & & 0.793 \\
\hline Chard $\mathrm{Na}$ & & -0.724 & & & 0.785 \\
\hline $\mathrm{P}_{2} \mathrm{O}_{5}$ & & 0.691 & & -0.467 & 0.858 \\
\hline EC & & -0.67 & & & 0.636 \\
\hline Chard Cu & & -0.466 & & & 0.266 \\
\hline Total phenolics & & & -0.933 & & 0.885 \\
\hline Total yield & & & 0.907 & & 0.913 \\
\hline Total biomass & & & 0.907 & & 0.951 \\
\hline First harvest & & & 0.902 & & 0.857 \\
\hline DPPH & & & -0.755 & & 0.668 \\
\hline Chard Mn & & & -0.684 & & 0.637 \\
\hline Silt & & & 0.68 & 0.458 & 0.702 \\
\hline Chard N & 0.577 & & 0.625 & & 0.865 \\
\hline $\mathrm{K}_{2} \mathrm{O}$ & -0.457 & -0.469 & 0.557 & & 0.745 \\
\hline Clay & & & & -0.825 & 0.941 \\
\hline Chard K & & & & 0.795 & 0.788 \\
\hline Fine sand & & & & 0.721 & 0.583 \\
\hline Chard Fe & & & & 0.703 & 0.757 \\
\hline
\end{tabular}


$\mathrm{CaCO}_{3}$ in soil. The content of $\mathrm{Fe}$ and $\mathrm{K}$ in chard was defined almost by silt as a soil physical constituent with readily available Fe and in relatively high extent of $\mathrm{K}$ for crop-uptake. The chard $\mathrm{Na}$ was controlled by humus and soil electrical conductivity. Although EC does not provide direct measurement of specific ions or salt compounds, it is correlated to concentrations of $\mathrm{Na}$ among the others such as nitrates, potassium, chloride, sulphate, and ammonia (Sposito, 2008).

The availability of $\mathrm{K}$ in soil in general positively affected the yield. The yield was in negative correlation with total phenolics determining antioxidant activity of chard. The content of total phenolics depended on $\mathrm{Mn}$ in chard due to role of $\mathrm{Mn}^{2+}$ ions as stimulator of phenylalanine ammonia-lyase as enzyme involved in metabolism of phenolics (Engelsma, 1972).

Considering that Swiss chard is a vegetable with numerous health benefits, which extracts and components possess biological activity proven in several researches (Ninfali et al.,

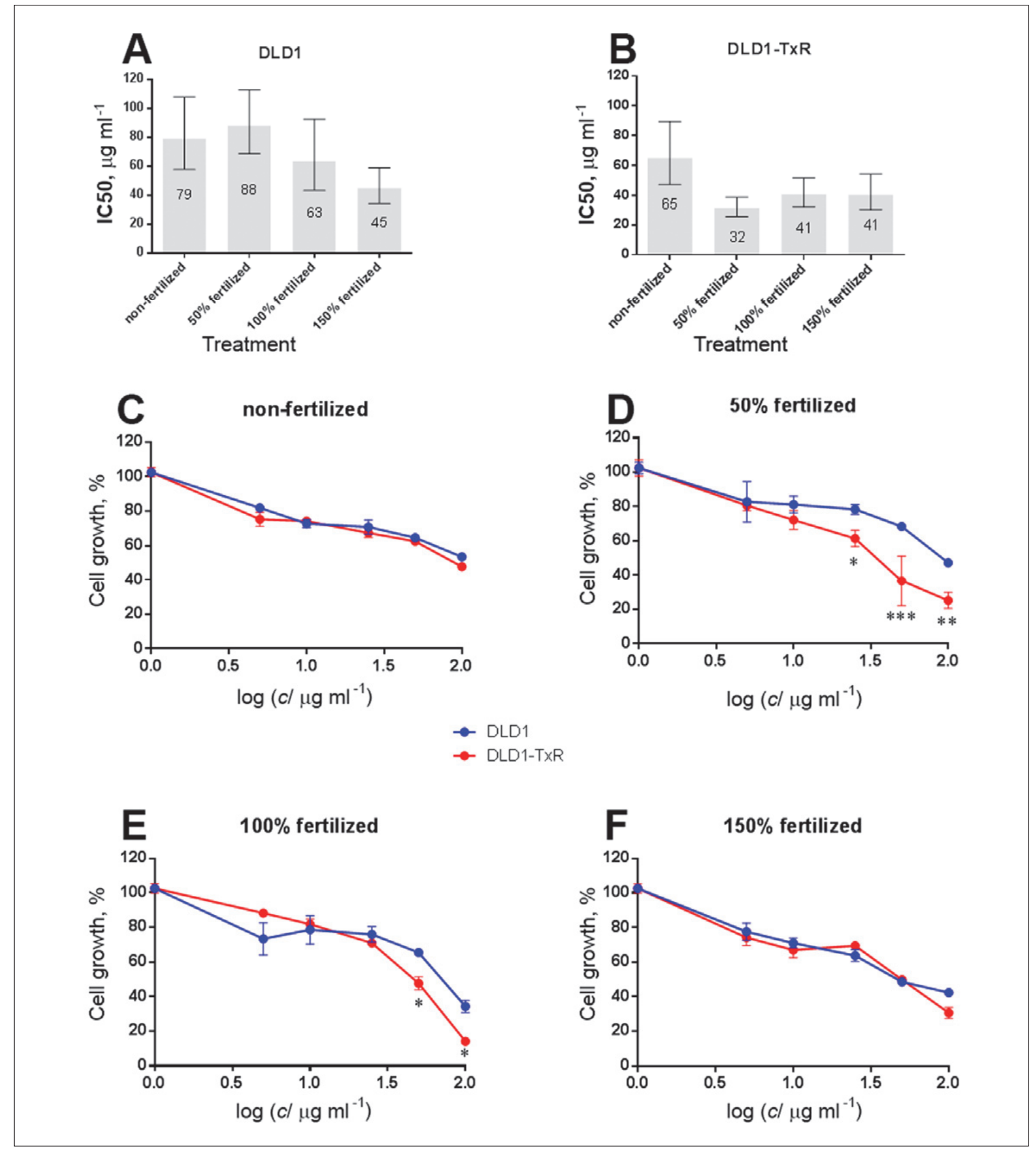

FIGURE 1. Colorectal carcinoma cell growth inhibition effects of Swiss chard extracts in sensitive DLD1 and multidrug resistant DLD1-TxR cell lines. IC50 values (numbers in columns) compared among extracts in DLD1 (A) and DLD1-TxR (B) cells. Cell growth inhibition obtained with extracts of non-fertilized (C), 50\% fertilized (D), 100\% fertilized (E), and 150\% fertilized (F) plants. Statistically significant difference in sensitivity of DLD1 and DLD1-TxR cells to investigated extracts: $p<0.05$ $(*) ; p<0.01(* *) ; p<0.001(* * *)$. 
2007; Trifunović et al., 2015), crude extracts from non-fertilized and fertilized (with different doses) Swiss chard were tested for their anticancer potential. To that end, the cell growth inhibition of two human colorectal carcinoma cell lines (DLD1 and DLD1-TxR) was studied by SRB assay (Figure 1). The results are expressed as concentrations of compounds that inhibited cell growth by 50\% (IC50) (Figure 1A and B). The greatest efficacy was obtained by Swiss chard extract from $150 \%$ fertilized plants in both DLD1 and DLD1-TxR cell lines. Although total phenolic contents of these extracts were the lowest, it is assumed that accumulation of certain phenolic compounds with powerful biological activity was favored under this fertilization. Vitexin, vitexin-2- $O$-xyloside and vitexin-2-O-rhamnoside are the principal antitumor molecules found in Swiss chard leaves and seeds (Ninfali et al., 2007). On the other hand, besides phenolic compounds, this effect also can be attributed to chlorophyll due to its important role in human cancer prevention (De la Rosa et al., 2010). Namely, measurement of chlorophyll content index in situ showed the highest average value - 51 CCI for $150 \%$ fertilized plants in comparison to the others $-44.8 \mathrm{CCI}$ for $100 \%$ fertilized and $42.8 \mathrm{CCI}$ for $50 \%$ fertilized plants. $100 \%$ and $150 \%$ fertilized samples were more active against DLD1 cells in comparison with non-fertilized sample (Figure 1A, B). It is important to note that all extracts from fertilized plants were significantly more potent against multidrug resistant DLD1-TxR cells comparing to extracts of non-fertilized plants (Figure 1A, B). $50 \%$ and $100 \%$ fertilized samples exerted a collateral sensitivity effect as they induced significantly higher growth inhibition of multidrug resistant DLD1-TxR cells (Figure 1D, E). The effects of non-fertilized and $150 \%$ fertilized samples were similar in both colorectal carcinoma cell lines (Figure 1C, F). However, extract from $150 \%$ fertilized plants was more efficient against both cell lines with IC50 values 2 -fold lower (around $40 \mu \mathrm{g} \mathrm{mL}^{-1}$ ) than that obtained with extract from non-fertilized plants (around $80 \mu \mathrm{g} \mathrm{mL}^{-1}$ ).

Conclusively, fertilization strategies with $50 \%$ and $100 \%$ nutrient doses were more efficient in multidrug resistant cancer cells (DLD1-TxR) than in their sensitive counterparts (DLD1), while $150 \%$ fertilization showed the same efficacy in both cell lines.

Considering that the main mechanism involved in multidrug resistant phenotype of DLD1-TxR cells is the overexpression of P-glycoprotein efflux pump (Podolski-Renić et al., 2011) responsible for the extrusion of various substrates including chemotherapeutics, the consumption of Swiss chard grown under adequate fertilization may: (i) evade the presence of multidrug resistant phenotype in colorectal carcinoma and (ii) increase the absorption of chemotherapeutics and other useful compounds in intestine. Further studies that would involve combination with classic chemotherapeutics used in clinical practice for colorectal carcinoma treatment are necessary to rationalize this concept.

\section{Conclusions}

The fertilization practices as well as soil properties can significantly influence yield and quality of Swiss chard, and its potential for antioxidant and biological activity.

The positive relationship was found between the content of $\mathrm{Ca}$ and $\mathrm{Mg}$ in chard and its exchangeable concentration in soil, as well as $\mathrm{Zn}$ and B in chard with soil carbonate component. The content of chard $\mathrm{P}$ was in positive relationship with available soil $\mathrm{P}$ (defined by $\mathrm{CaCO}_{3}$ ). The negative relationship was found between the content of $\mathrm{Cu}$ in chard and $\mathrm{CaCO}_{3}$, and positive with soil electrical conductivity. The content of $\mathrm{Fe}$ and $\mathrm{K}$ in chard was defined by silt, and chard $\mathrm{Na}$ by humus and EC.

The fertilization at $50 \%$ of recommended level negatively affected yield and positively antioxidant activity, while fertilization at $150 \%$ of recommended level had a contrary effect. Total phenolics were in positive correlation with the chard $\mathrm{Mn}$ and in negative correlation with yield. The greatest efficacy in human colorectal carcinoma cell lines (DLD1 and DLD1-TxR) was obtained by Swiss chard extract from plants fertilized at $150 \%$ of recommended level.

\section{Acknowledgments}

Research was supported by the projects: "INGAF" (Ministry of Science of Montenegro), Centre of Excellence in Bioinformatics "BIO-ICT" (Higher Education and Research for Innovation and Competitiveness project, Contract No. 011001) and "Agricultural Adaptation to Climate Change - Networking, Education, Research and Extension" (Norwegian Programme in Higher Education, Research and Development in Western Balkans).

\section{References}

Baize, D. (1993). Soil Science Analyses. A Guide to Current Use (Chichester: John Wiley and Sons).

Bozokalfa, M.K., Yağmur, B., Așçığul, T.K., and Eşiyok, D. (2011). Diversity in nutritional composition of Swiss chard (Beta vulgaris subsp. L. var. cicla) accessions revealed by multivariate analysis. Plant Genet. Resour. 9(04), 557-566. https://doi.org/10.1017/ S1479262111000876.

Daiss, N., Lobo, M., and González, M. (2008a). Changes in postharvest quality of Swiss chard grown using 3 organic preharvest treatments. J. Food Sci. 73, S314-S320. https://doi.org/10.1111/j.17503841.2008.00842.x.

Daiss, N., Lobo, M.G., Socorro, A.R., Bruckner, U., Heller, J., and González, M. (2008b). The effect of three organic pre-harvest treatments on Swiss chard (Beta vulgaris L. var. cycla L.) quality. Eur. Food Res. Technol. 226, 345-353. https://doi.org/10.1007/s00217006-0543-2.

De la Rosa, L.A., Alvarez-Parrilla, E., and Gonzalez-Aguilar, G.A. (2010). Fruit and Vegetable Phytochemicals: Chemistry, Nutritional Value and Stability (Hoboken, N.J.: Wiley-Blackwell).

Džamić, R., Petrović, M., and Jakovljević, M. (1996). Praktikum iz Agrohemije (Belgrade: Faculty of Agriculture).

Engelsma, G. (1972). A possible role of divalent manganese in photoinduction of phenylalanine-ammonia lyase. Plant Physiol. 50, 599-602. https://doi.org/10.1104/pp.50.5.599.

Gebrekidan, A., Weldegebriel, Y., Hadera, A., and Bruggen, B.V. (2013). Toxicological assessment of heavy metals accumulated in vegetables and fruits grown in Ginfel river near Sheba Tannery, Tigray, Northern Ethiopia. Ecotoxicol. Environ. Saf. 95, 171-178. https://doi.org/10.1016/j.ecoenv.2013.05.035.

Goldberg, S. (1997). Reactions of boron with soils. Plant Soil. 193, 35-48. https://doi.org/10.1023/A:1004203723343.

Knežević, M., Đurović, D., Mugoša, B., Strunjaš, M., and Topalović, A. (2014). Relationships between parameters of soil and chard (Beta vulgaris L. var. cicla L.). Agric. and Forestry 60(3), 275-283.

Kuo, S.M., Leavitt, P.S., and Lin, C.P. (1998). Dietary flavonoids interact with trace metals and affect metallothionein level in human intestinal cells. Biol. Trace Element Res. 62, 135-153. https://doi. org/10.1007/BF02783967. 
Marschner, H. (1995). Mineral Nutrition of Higher Plants, $2^{\text {nd }}$ edn. (London: Academic Press).

Maynard, D.N., and Hochmuth, G.J. (1997). Knott's Handbook for Vegetable Growers, $4^{\text {th }}$ edn. (New York: John Wiley and Sons).

Miceli, A., and Miceli, C. (2014). Effect of nitrogen fertilization on the quality of Swiss chard at harvest and during storage as minimally processed produce. J. Food Qual. 37, 125-134. https:// doi.org/10.1111/jfq.12073.

Mishra, K., Ojha, H., and Chaudhury, N.K. (2012). Estimation of antiradical properties of antioxidants using DPPH assay: A critical review and results. Food Chem. 130, 1036-1043. https://doi. org/10.1016/j.foodchem.2011.07.127.

Ninfali, P., and Angelino, D. (2013). Nutritional and functional potential of Beta vulgaris cicla and rubra. Fitoterapia 89(1), 188199. https://doi.org/10.1016/j.fitote.2013.06.004

Ninfali, P., Bacchiocca, M., Antonelli, A., Biagiotti, E., Di Gioacchino, A.M., Piccoli, G., Stocchi, V., and Brandi, G. (2007). Characterization and biological activity of the main flavonoids from Swiss Chard (Beta vulgaris subsp. cycla). Phytomedicine 14, 216-221. https://doi. org/10.1016/j.phymed.2006.03.006

Podolski-Renić, A., Anđelković, T., Banković, J., Tanić, N., Ruždijić, S., and Pešić, M. (2011). The role of paclitaxel in the development and treatment of multidrug resistant cancer cell lines. Biomed. Pharmacother. $\quad 65, \quad 345-353$. https://doi.org/10.1016/j. biopha.2011.04.015.

Pokluda, R., and Kuben, J. (2002). Comparison of selected Swiss chard (Beta vulgaris ssp. cicla L.) varieties. Hortic. Sci. (Prague) 29, 114-118. https://doi.org/10.17221/4473-HORTSCI.

Pyo, Y.H., Lee, T.C., Logendra, L., and Rosen, R.T. (2004). Antioxidant activity and phenolic compounds of Swiss chard (Beta vulgaris subsp. cycla) extracts. Food Chem. 85, 19-26. https://doi.org/10.1016/ S0308-8146(03)00294-2.

Schirrmacher, G., Skurk, T., Hauner, H., and Graßmann, J. (2010). Effect of Spinacia oleraceae L. and Perilla frutescens L. on antioxidants and lipid peroxidation in an intervention study in healthy individuals. Plant Foods Hum. Nutr. 65(1), 71-76. https://doi.org/10.1007/ s11130-009-0152-x.

Sposito, G. (2008). The Chemistry of Soils, $2^{\text {nd }}$ edn. (New York: Oxford University Press)

Ström, L. (1997). Root exudation of organic acids: importance to nutrient availability and the calcifuge and calcicole behaviour of plants. Oikos 80(3), 459-466. https://doi.org/10.2307/3546618.

Stumm, W. (1992). Chemistry of the Solid-Water Interface (New York: Wiley).

Topalović, A., Pfendt, L., Perović, N., Đorđević, D., Trifunović, S., and Pfendt, P. (2006). The chemical characteristics of soil which determine phosphorus partitioning in highly calcareous soils. J. Serb. Chem. Soc. 71(11), 1219-1236. https://doi.org/10.2298/ JSC0611219T

Topalović, A., Knežević, M., and Vajs, V. (2013). Total phenolics and antioxidants from fruits and vegetables: Evaluation of daily intake. Agric. and Forestry 59(1), 143-154.

Trifunović, S., Topalović, A., Knežević, M., and Vajs, V. (2015). Free radicals and antioxidants: antioxidative and other properties of Swiss chard (Beta vulgaris L. subsp. cicla). Agric. and Forestry 61(2), 73-92. https://doi.org/10.17707/AgricultForest.61.2.06.

U.S. Department of Agriculture, Agricultural Research Service (2014). USDA National Nutrient Database for Standard Reference, Release 27. Nutrient Data Laboratory Home Page, http://www.ars. usda.gov/ba/bhnrc/ndl.
Wu, Y.Y., and Zhao, K. (2013). Root-exuded malic acid versus chlorophyll fluorescence parameters in four plant species under different phosphorus levels. J. Soil Sci. Plant Nutr. 13(3), 604-610. https://doi.org/10.4067/S0718-95162013005000048.

Yoshino, M., and Murakami, K. (1998). Interaction of iron with polyphenolic compounds: application to antioxidant characterization. Anal. Biochem. 257, 40-44. https://doi. org/10.1006/abio.1997.2522.

Received: May 12, 2017

Accepted: Sep. 10, 2017

Addresses of authors:

Ana Topalović ${ }^{1, *}$, Mirko Knežević ${ }^{1}$, Snežana Trifunović ${ }^{2}$ Miroslav Novaković ${ }^{3}$, Milica Pešić ${ }^{4}$ and Dijana Đurović 5

${ }^{1}$ University of Montenegro, Biotechnical Faculty, Center for Soil Research and Melioration, Mihaila Lalića 15, 81000, Podgorica, Montenegro

${ }^{2}$ University of Belgrade, Faculty of Chemistry, Studentski trg 16, 11158 Belgrade, Serbia

${ }^{3}$ University of Belgrade, Institute of Chemistry, Technology and Metallurgy, National Institute, Studentski trg 12-16,

11158 Belgrade, Serbia

${ }^{4}$ University of Belgrade, Institute for Biological Research,

Bulevar despota Stefana 142, 11060 Belgrade, Serbia

${ }^{5}$ Institute for Public Health, Džona Džeksona bb, 81000

Podgorica, Montenegro

*Corresponding author; E-mail: anato@ucg.ac.me

Tel. : +38269306320 